\title{
A Comprehensive Assessment of Water Quality at the Rosetta Branch of the Nile River, Egypt
}

\author{
Mohamed Mostafa and Robert W. Peters \\ Department of Civil, Construction and Environmental Engineering, University of Alabama at Birmingham, Birmingham, AL 35294, \\ USA
}

\begin{abstract}
The aim of the present study is to assess the water quality along the Rosetta branch of the Nile River, Egypt. The study area extends from upstream of the El-Rahawy drain to the end of the branch. The correlation matrix was performed to help identify the nature of correlations between the different parameters. The WQI (water quality index) was calculated seasonally at different points along the Rosetta branch to provide a simple indicator of water quality at these points. The results of WQI calculations showed that the fecal coliform is the main cause of poor water quality along the Rosetta branch. A statistical analysis was also performed using a two-way ANOVA (analysis of variance) to identify the significant sources of water pollution and to determine the impact of the parameters on a mass loading. A significant difference was observed between the impacts of the pollution sources on the water quality. Also, a significant difference was observed between the impacts of each parameter in the mass loading. The results showed that the El-Rahawy, Tala and Sabal drains are the major sources for water quality degradation along the Rosetta branch and that the effect of the El-Tahrir and the Zawyet El-Baher drains on the water quality is not significant.
\end{abstract}

Key words: Physicochemical analysis, analysis of variance, water quality index, correlation matrix, Rosetta branch, Egypt.

\section{Introduction}

The longest river in the world, the Nile River measures $6,700 \mathrm{~km}(4,163.2 \mathrm{mi})$ long and runs from Lake Victoria in east central Africa to the Mediterranean Sea in northeastern Egypt. The drainage area of the Nile basin is 2,900,000 $\mathrm{km}^{2}$ $\left(1,119,696.2 \mathrm{mi}^{2}\right)$. The Nile River passes through the countries of Egypt, Sudan, Ethiopia, Uganda, Kenya, Tanzania, Democratic Republic of the Congo, Rwanda, and Burundi [1]. As an arid country of high temperatures and low rainfall, Egypt depends on the Nile River for more than $95 \%$ of its fresh water needs [2]. The river travels for $950 \mathrm{~km}$ through Egypt, starting from Aswan in the south and ending at Cairo in the north, where it separates into two branches, Rosetta and Damietta branches, which form the Nile Delta [3].

The average flow rate of this branch is about $21,500,000 \mathrm{~m}^{3} /$ day $(5,679,698,000 \mathrm{gal} /$ day $)$ [4]. The

Corresponding author: Mohamed Mostafa, Ph.D., research field: environmental engineering.
Rosetta branch daily receives more than 3 million $\mathrm{m}^{3}$ of agricultural drainage water, in addition to receiving untreated and partially treated industrial and domestic wastewaters [3], as well as toxic dumping. Five agricultural drains empty into the branch: the El-Rahawy, the Sabal, the El-Tahrer, the Zawyet El-Bahr, and the Tala [5]. At the El-Rahawy drain, considered as the main source of pollution along the Rosetta branch [6], the water quality is greatly affected by two primary pollution sources: (1) small drains located along its path that discharge agriculture and domestic wastewater without prior treatment; and (2) the El-Mansoria Canal, which receives secondary treated wastewater from the Zenen WWTP (Wastewater Treatment Plant) and primary treated wastewater from the Abu-Rawash WWTP [7]. Several studies have been conducted to address water quality at the Rosetta branch. Abdel-Satar and Elewa [8] observed low levels of DO (dissolved oxygen) at the discharge points of the El-Rahawy drain. Abdo [9] concluded that the El-Rahawy and the Sabal drains 
comprise the major sources of pollutants along the Rosetta branch due to the large amount of domestic, industrial, and agricultural wastes discharged from these drains. Other studies of water quality at the Rosetta branch included that of Elewa et al. [10], who determined that the El-Rahawy drain constitutes the major source of pollution along the Rosetta branch because the drain discharges large amounts of agricultural and domestic wastewaters. Also, El Bouraie et al. [7] found high concentrations of inorganic and organic pollutants at the discharge point of the El-Rahawy drain, with a resultant adverse effect on water quality at the Rosetta branch.

\section{Materials and Methods}

The survey, performed in the Rosetta branch, involved collecting water samples in winter, spring, summer, and autumn 2013. Fig. 1 shows the sampling points along the study area. 17 stations were chosen along the Rosetta branch in order to cover the main polluted areas along the branch: 10 upstream and downstream from the point sources; 5 at the discharge point of the point source; 1 at the middle distance between the last pollution source and the end of the branch; and the last station located at the end of the branch, as shown in Table 1. The point sources located along the study area include the El-Rahawy drain, the Sabal drain, the El-Tahrir drain, the Zawyet El-Baher drain, and the Tala drain.

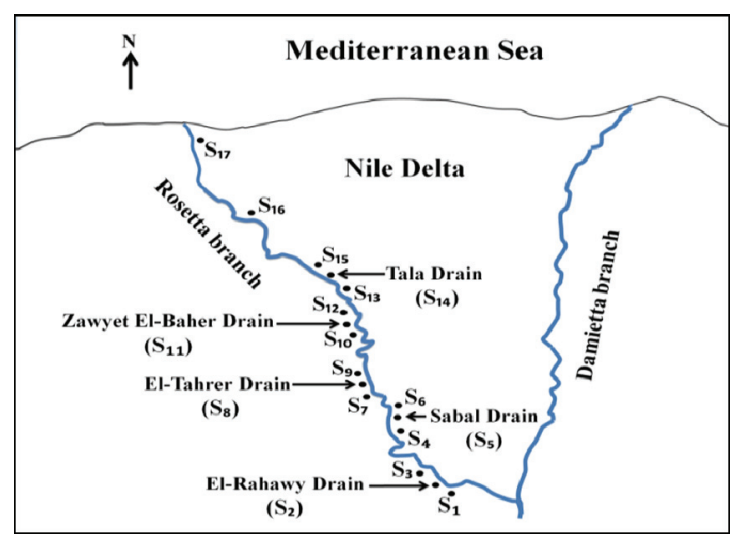

Fig. 1 Map of the sampling stations along the Rosetta branch.
Table 1 Location of the study stations along the Rosetta branch.

\begin{tabular}{ll}
\hline $\begin{array}{l}\text { Station } \\
\text { code }\end{array}$ & Description \\
\hline $\mathrm{S}_{1}$ & Upstream of the El-Rahawy drain \\
$\mathrm{S}_{2}$ & At discharge point of the El-Rahawy drain \\
$\mathrm{S}_{3}$ & Downstream of the El-Rahawy drain \\
$\mathrm{S}_{4}$ & Upstream of the Sabal drain \\
$\mathrm{S}_{5}$ & At discharge point of the Sabal drain \\
$\mathrm{S}_{6}$ & Downstream of the Sabal drain \\
$\mathrm{S}_{7}$ & Upstream of the El-Tahrir drain \\
$\mathrm{S}_{8}$ & At discharge point of the El-Tahrir drain \\
$\mathrm{S}_{9}$ & Downstream of the El-Tahrir drain \\
$\mathrm{S}_{10}$ & Upstream of the Zawyet El-Baher drain \\
$\mathrm{S}_{11}$ & At discharge point of the Zawyet El-Baher drain \\
$\mathrm{S}_{12}$ & Downstream of the Zawyet El-Baher drain \\
$\mathrm{S}_{13}$ & Upstream of the Tala drain \\
$\mathrm{S}_{14}$ & At discharge point of the Tala drain \\
$\mathrm{S}_{15}$ & Downstream of the Tala drain \\
$\mathrm{S}_{16}$ & Downstream of the El-Kwa Water Treatment Plant \\
$\mathrm{S}_{17}$ & At end of the Rosetta branch \\
\hline
\end{tabular}

Water samples were collected from a depth of approximately $0.3 \mathrm{~m}$ (1 foot) below the surface with the use of 2-liter plastic containers. After their placement in an ice chest and were then transported to the laboratory, water samples were analyzed for TDS (total dissolved solids), TSS (total suspended solids), BOD (biochemical oxygen demand), COD (chemical oxygen demand), TOC (total organic carbon), $\mathrm{DO}, \mathrm{Cl}^{-}$ (chlorides), $\mathrm{NO}_{3}{ }^{-}$(nitrates), $\mathrm{PO}_{4}{ }^{3-}$ (total phosphate), turbidity, $\mathrm{pH}$ and temperature. The samples were analyzed according to the standard methods for wastewater analysis [11]. Results of the analysis were then compared with standards specified in Egyptian Law 48/1982 and EPA (Environmental Protection Agency) standards $[12,13]$. The WTW multi $340 \mathrm{i}$ meter (JERMANY/WTW 340i/05281018) enabled measurement of $\mathrm{DO}, \mathrm{pH}$ and temperature values in the field. The meter automatically adjusts DO and temperature. Four buffer solutions with $\mathrm{pH}$ values of 4.0, 7.0 and 10.0 were used for the multi meter calibration. The TDS/EC meter (HM Digital/COM-80/891144000229) was used to measure the TDS concentration in the field. For quality control 
purposes, a solution with known concentration allowed assessment of the accuracy of measurements. Analysis of the other parameters took place in HBRC (Egyptian Housing Building Research Center) laboratory, located in Cairo City. Turbidity was measured by using the turbidity meter (COLE PALMER- USA/08391.45/12106698). For quality control purposes, testing of a solution with a known concentration ensured accuracy of the measurements. The TOC concentration was measured by using a TOC analyzer (Shimadzu/4200) [11]; An automatic calibration conducted by using dilution water as a standard solution ascertained the accuracy of the data. The 5-day BOD test 5210B was used in the determination of the BOD concentration in wastewater samples [11]. For quality control purposes, the research protocol included the following procedures: (1) In seed control samples tested after 5 days of incubation, a minimum residual DO of $1.0 \mathrm{mg} / \mathrm{L}$ and a minimum DO depletion of $2.0 \mathrm{mg} / \mathrm{L}$ were required; (2) the glucose-glutamic acid solution and the dilution water were tested and compared with the acceptable limits. Use of the closed reflux, titrimetric method $5220 \mathrm{C}$ enabled determination of the COD concentration in the samples [11]. For quality control purposes, testing of a solution with known concentration ensured accuracy of the measurements. Test method 2540D was used for the determination of TSS [11]. For quality control purposes, analysis of $20 \%$ of the total number of samples took place. Fecal coliform membrane filter technique 9222D was used to determine the $\mathrm{FC}$ (fecal coliform) density in the samples [11]. The $\mathrm{NO}_{3}^{-}, \mathrm{PO}_{4}{ }^{3-}$ and $\mathrm{Cl}^{-}$were measured by applying ion chromatography method 4110B [11]. For quality control purposes, the sample loop and the needle were flushed with $250.0 \mathrm{~mL}$ of deionized water; The temperature of the column was set at $30^{\circ} \mathrm{C}$. After running occurred, the time and the resolution of the peaks were checked. The time and the resolution of the peaks must approximate those of the chromatogram of the column.
A correlation matrix, performed with the use of Microsoft Office Excel 2010, yielded the nature of correlations among the different parameters. A two-way ANOVA (analysis of variance) was used to identify the impact of each point source on the water quality of the Nile Delta, the major source of water pollution along the study area, the impact of each parameter on a mass loading, and the influence of the parameters on each other. The parameters included $\mathrm{pH}, \mathrm{COD}, \mathrm{BOD}, \mathrm{TOC}$, TSS, TDS, chlorides, and DO. 10 groups were established: Two groups followed the mass loading theory (flow $\times$ concentration), while the other groups followed the loading factor concept (flow $\times$ solids concentration $\times$ organics concentration), as shown in Table 2. The first two groups comprise $\mathrm{DO}$ and $\mathrm{pH}$ $\left(-\log \left[\mathrm{H}^{+}\right]\right)$multiplied by the flow rate. The other groups contain solids multiplied by organics and flow rate, where the solids are bound to organics in water.

The WQI (water quality index) was calculated seasonally at different points along the study area to provide a simple indicator of water quality at these points. WQI is an excellent and reliable tool used to measure and monitor changes in water quality. Several water quality parameters are used to calculate the WQI, including TS (total solids), DO, BOD, FC, pH, turbidity, $\mathrm{NO}_{3}{ }^{-}, \mathrm{PO}_{4}{ }^{3-}$ and temperature. The index was determined with the use of the NSF (National Sanitation Foundation) method [14]. The mathematical expression for NSF WQI is given by:

$$
\begin{gathered}
N S F W Q I=\Sigma W_{X} Q_{X}=W_{\mathrm{pH}} \times Q_{\mathrm{pH}}+ \\
W_{\text {Phosphate }} \times Q_{\text {Phosphate }}+W_{\text {Nitrate }} \times Q_{\text {Nitrate }}+ \\
W_{\text {DO sat } \%} \times Q_{\mathrm{DO} \text { sat } \%}+W_{\mathrm{TS}} \times Q_{\mathrm{TS}}+W_{\mathrm{FC}} \times Q_{\mathrm{FC}}+ \\
W_{\mathrm{BOD}} \times Q_{\mathrm{BOD}}+W_{\text {Turbidity }} \times Q_{\text {Turbidity }}+ \\
W_{\text {Temp }} \times Q_{\text {Temp. }}
\end{gathered}
$$

where, $W_{X}$ is weight factors of the water quality parameters, $Q_{X}$ is Q-value of the water quality parameters, and $X=$ water quality parameters. The weight factors for $\mathrm{DO}, \mathrm{FC}, \mathrm{pH}, \mathrm{BOD}$, temperature, $\mathrm{PO}_{4}{ }^{3-}, \mathrm{NO}_{3}{ }^{-}$, turbidity, and TS are $0.17,0.16,0.11$, $0.11,0.1,0.1,0.1,0.08$ and 0.07 , respectively [14]. After calculation of WQI values took place, the values 
Table 2 ANOVA terms (interaction between organic and solid factors).

\begin{tabular}{|c|c|c|c|c|c|}
\hline Pollution source/parameter & COD, TSS & COD, TDS & BOD, TSS & BOD, TDS & DO \\
\hline PS1 & $\mathrm{Q}_{\mathrm{n}_{1}} \times \mathrm{C}_{\mathrm{COD}_{1}} \times \mathrm{C}_{\mathrm{TSS}_{1}}$ & $\mathrm{Q}_{\mathrm{n} 1} \times \mathrm{C}_{\mathrm{COD}_{1}} \times \mathrm{C}_{\mathrm{TDS}_{1}}$ & $\mathrm{Q}_{\mathrm{n}_{1}} \times \mathrm{C}_{\mathrm{BOD}_{1}} \times \mathrm{C}_{\mathrm{TSS}_{1}}$ & $\mathrm{Q}_{\mathrm{n}_{1}} \times \mathrm{C}_{\mathrm{BOD}_{1}} \times \mathrm{C}_{\mathrm{TDS}_{1}}$ & $\mathrm{Q}_{\mathrm{n}_{1}} \times \mathrm{C}_{\mathrm{DO}_{1}}$ \\
\hline PS2 & $\mathrm{Q}_{\mathrm{n}_{2}} \times \mathrm{C}_{\mathrm{COD}_{2}} \times \mathrm{C}_{\mathrm{TSS}_{2}}$ & $\mathrm{Q}_{\mathrm{n}_{2}} \times \mathrm{C}_{\mathrm{COD}_{2}} \times \mathrm{C}_{\mathrm{TDS}_{2}}$ & $\mathrm{Q}_{\mathrm{n} 2} \times \mathrm{C}_{\mathrm{BOD}_{2}} \times \mathrm{C}_{\mathrm{TSS}_{2}}$ & $\mathrm{Q}_{\mathrm{n}_{2}} \times \mathrm{C}_{\mathrm{BOD}_{2}} \times \mathrm{C}_{\mathrm{TDS}_{2}}$ & $\mathrm{Q}_{\mathrm{n}_{2}} \times \mathrm{C}_{\mathrm{DO}_{2}}$ \\
\hline PS3 & $\mathrm{Q}_{\mathrm{n} 3} \times \mathrm{C}_{\mathrm{COD} 3} \times \mathrm{C}_{\mathrm{TSS}_{3}}$ & $\mathrm{Q}_{\mathrm{n} 3} \times \mathrm{C}_{\mathrm{COD} 3} \times \mathrm{C}_{\mathrm{TDS} 3}$ & $\mathrm{Q}_{\mathrm{n} 3} \times \mathrm{C}_{\mathrm{BOD} 3} \times \mathrm{C}_{\mathrm{TSS} 3}$ & $\mathrm{Q}_{\mathrm{n} 3} \times \mathrm{C}_{\mathrm{BOD} 3} \times \mathrm{C}_{\mathrm{TDS} 3}$ & $\mathrm{Q}_{\mathrm{n} 3} \times \mathrm{C}_{\mathrm{DO} 3}$ \\
\hline PS4 & $\mathrm{Q}_{\mathrm{n} 4} \times \mathrm{C}_{\mathrm{COD} 4} \times \mathrm{C}_{\mathrm{TSS}_{4}}$ & $\mathrm{Q}_{\mathrm{n} 4} \times \mathrm{C}_{\mathrm{COD} 4} \times \mathrm{C}_{\mathrm{TDS} 4}$ & $\mathrm{Q}_{\mathrm{n} 4} \times \mathrm{C}_{\mathrm{BOD} 4} \times \mathrm{C}_{\mathrm{TSS}_{4}}$ & $\mathrm{Q}_{\mathrm{n} 4} \times \mathrm{C}_{\mathrm{BOD} 4} \times \mathrm{C}_{\mathrm{TDS} 4}$ & $\mathrm{Q}_{\mathrm{n} 4} \times \mathrm{C}_{\mathrm{DO}_{4}}$ \\
\hline PS5 & $\mathrm{Q}_{\mathrm{n}_{5}} \times \mathrm{C}_{\mathrm{COD}_{5}} \times \mathrm{C}_{\mathrm{TSS}_{5}}$ & $\mathrm{Q}_{\mathrm{n}_{5}} \times \mathrm{C}_{\mathrm{COD}_{5}} \times \mathrm{C}_{\mathrm{TDS} 5}$ & $\mathrm{Q}_{\mathrm{n} 5} \times \mathrm{C}_{\mathrm{BOD}_{5}} \times \mathrm{C}_{\mathrm{TSS} 5}$ & $\mathrm{Q}_{\mathrm{n} 5} \times \mathrm{C}_{\mathrm{BOD}_{5}} \times \mathrm{C}_{\mathrm{TDS}_{5}}$ & $\mathrm{Q}_{\mathrm{n} 5} \times \mathrm{C}_{\mathrm{DO}_{5}}$ \\
\hline Pollution source/parameter & TOC, TSS & TOC, TDS & $\mathrm{Cl}^{-}, \mathrm{TSS}$ & $\mathrm{Cl}^{-}, \mathrm{TDS}$ & $\mathrm{pH}$ \\
\hline PS1 & $\mathrm{Q}_{\mathrm{n}_{1}} \times \mathrm{C}_{\mathrm{TOC}_{1}} \times \mathrm{C}_{\mathrm{TSS}_{1}}$ & $\mathrm{Q}_{\mathrm{n}_{1}} \times \mathrm{C}_{\mathrm{TOC}_{1}} \times \mathrm{C}_{\mathrm{TDS}_{1}}$ & $\mathrm{Q}_{\mathrm{n}_{1}} \times \mathrm{C}_{\mathrm{Cl}_{-1}} \times \mathrm{C}_{\mathrm{TSS}_{1}}$ & $\mathrm{Q}_{\mathrm{n}_{1}} \times \mathrm{C}_{\mathrm{Cl}-1_{1}} \times \mathrm{C}_{\mathrm{TDS}_{1}}$ & $\mathrm{Q}_{\mathrm{n}_{1}} \times \mathrm{pH}_{1}$ \\
\hline PS2 & $\mathrm{Q}_{\mathrm{n} 2} \times \mathrm{C}_{\mathrm{TOC}_{2}} \times \mathrm{C}_{\mathrm{TSS}_{2}}$ & $\mathrm{Q}_{\mathrm{n} 2} \times \mathrm{C}_{\mathrm{TOC}_{2}} \times \mathrm{C}_{\mathrm{TDS} 2}$ & $\mathrm{Q}_{\mathrm{n} 2} \times \mathrm{C}_{\mathrm{Cl}-2} \times \mathrm{C}_{\mathrm{TSS} 2}$ & $\mathrm{Q}_{\mathrm{n} 2} \times \mathrm{C}_{\mathrm{Cl}-2} \times \mathrm{C}_{\mathrm{TDS} 2}$ & $\mathrm{Q}_{\mathrm{n} 2} \times \mathrm{pH}_{2}$ \\
\hline PS3 & $\mathrm{Q}_{\mathrm{n}_{3}} \times \mathrm{C}_{\mathrm{TOC}_{3}} \times \mathrm{C}_{\mathrm{TSS}_{3}}$ & $\mathrm{Q}_{\mathrm{n}_{3}} \times \mathrm{C}_{\mathrm{TOC}_{3}} \times \mathrm{C}_{\mathrm{TDS} 3}$ & $\mathrm{Q}_{\mathrm{n} 3} \times \mathrm{C}_{\mathrm{Cl}-3} \times \mathrm{C}_{\mathrm{TSS}_{3}}$ & $\mathrm{Q}_{\mathrm{n} 3} \times \mathrm{C}_{\mathrm{Cl}-3} \times \mathrm{C}_{\mathrm{TDS} 3}$ & $\mathrm{Q}_{\mathrm{n} 3} \times \mathrm{pH}_{3}$ \\
\hline PS4 & $\mathrm{Q}_{\mathrm{n}_{4}} \times \mathrm{C}_{\mathrm{TOC}_{4}} \times \mathrm{C}_{\mathrm{TSS}_{4}}$ & $\mathrm{Q}_{\mathrm{n}_{4}} \times \mathrm{C}_{\mathrm{TOC}_{4}} \times \mathrm{C}_{\mathrm{TDS}_{4}}$ & $\mathrm{Q}_{\mathrm{n}_{4}} \times \mathrm{C}_{\mathrm{Cl}_{-4}} \times \mathrm{C}_{\mathrm{TSS}_{4}}$ & $\mathrm{Q}_{\mathrm{n} 4} \times \mathrm{C}_{\mathrm{Cl}-4} \times \mathrm{C}_{\mathrm{TDS}_{4}}$ & $\mathrm{Q}_{4} \times \mathrm{pH}_{4}$ \\
\hline PS5 & $\mathrm{Q}_{\mathrm{n}_{5}} \times \mathrm{C}_{\mathrm{TOC}_{5}} \times \mathrm{C}_{\mathrm{TSS}_{5}}$ & $\mathrm{Q}_{\mathrm{n}_{5}} \times \mathrm{C}_{\mathrm{TOC}_{5}} \times \mathrm{C}_{\mathrm{TDS}_{5}}$ & $\mathrm{Q}_{\mathrm{n}_{5}} \times \mathrm{C}_{\mathrm{Cl}-5} \times \mathrm{C}_{\mathrm{TSS} 5}$ & $\mathrm{Q}_{\mathrm{n}_{5}} \times \mathrm{C}_{\mathrm{Cl}_{-5}} \times \mathrm{C}_{\mathrm{TDS}_{5}}$ & $\mathrm{Q}_{\mathrm{n} 5} \times \mathrm{pH}_{5}$ \\
\hline
\end{tabular}

Notation: Q, flow rate from pollution source; PS, pollution source; PS1, El-Rahawy drain; PS2, Sabal drain; PS3, El-Tahrir drain; PS4, Zawyet El-Baher drain; PS5, Tala drain.

were then classified into five categories, as follows:

- $0 \sim 24$, poor water;

- 25 49, bad water;

- 50 69, medium water;

- 70 89, good water;

- $90 \sim 100$, excellent water [14].

\section{Results and Discussion}

\subsection{Physicochemical Analysis}

Results of physicochemical analysis of water samples collected along the Rosetta branch during the four seasons are presented in the Appendix in Tables A1 and A2.

\subsubsection{The $\mathrm{pH}$ Value}

The $\mathrm{pH}$ value represents the master control parameter for chemical and biological reactions in a water body. The optimum $\mathrm{pH}$ for most aquatic species ranges from 6.5 to 9 [15]. Tables $\mathrm{A} 1$ and $\mathrm{A} 2$ show that $\mathrm{pH}$ values for all water samples collected along the Rosetta branch were alkaline and within the permissible limits. In the hot season, the growth of aquatic plants in the Nile River increases the $\mathrm{pH}$ value of water because plants consume carbon dioxide in the photosynthesis process, which leads to increased alkalinity of the water. On the other hand, during the cold season, the phytoplankton consumes less carbon dioxide, which leads to increased carbonic acid
$\left(\mathrm{H}_{2} \mathrm{CO}_{3}\right)$ content in the water and, as a result, to increased water acidity. The highest $\mathrm{pH}$ value (8.3) was recorded at Station $\mathrm{S}_{1}$ (upstream of the El-Rahawy drain) during the summer season because, when water alkalinity increases in hot weather because the aquatic plants consume more carbon dioxide. The lowest value (7.22) was found at Station $\mathrm{S}_{2}$ (at discharge point of the El-Rahawy drain) during the winter season because water acidity increases in cold weather as a function of increased carbonic acid content that develops in the water when phytoplankton consume less carbon dioxide. The data analysis showed that the $\mathrm{pH}$ level along the study area did not adversely affected by climate change or receiving discharge from point sources located along the branch.

\subsubsection{Turbidity}

Turbidity is a water quality indicator measures water transparency. In open water, turbidity results primarily from suspended particles such as silt, clay, fine sand, plankton, microbes, algae, and other substances. These materials usually range in size from $0.004 \mathrm{~mm}$ (clay) to $1.0 \mathrm{~mm}$ (sand) [16]. Turbidity values along the Rosetta branch ranged from 4.5 to 54 NTU (nephelometric turbidity unit) during all seasons which exceeded the limits specified in Law 48/1982 and EPA standards (20 NTU) [12, 13]. The highest values for this parameter were recorded at 
Stations $\mathrm{S}_{2}, \mathrm{~S}_{5}$ (at discharge point of the Sabal drain) and $\mathrm{S}_{14}$ (at discharge point of the Tala drain), as shown in Tables A1 and A2. The increase in turbidity concentration at these stations is attributed to the discharge of domestic, agricultural, and industrial effluents from El-Rahawy, Sabal and Tala drains, which increased the concentration of suspended solids at the Rosetta branch. Because suspended particles absorb more heat energy, rise in water temperatures was also found at these stations as a result of high turbidity. The production of DO can also decrease because the rate of photosynthesis lessens as a result of the turbidity which reduces the amount of sunlight penetrating the water. High turbidity at Stations $\mathrm{S}_{2}, \mathrm{~S}_{5}$ and $\mathrm{S}_{14}$ can affect surface fish populations by shifting fish populations to species that feed on the river bottom. High turbidity can also increase the cost of surface water treatment for the drinking water supply [17].

\subsubsection{Total Dissolved Solids}

TDS can be defined as all organic and inorganic dissolved substances that can pass through a filter paper $(2 \mu \mathrm{m})$ when a sample of water is filtered. The inorganic substances usually include potassium, calcium, sodium, magnesium, chlorides, sulfates and bicarbonates. The organic ions include hydrocarbons, plant debris and herbicides, in addition, soil organic materials such as fulvic and humic acids help to comprise TDS $[18,19]$. Tables A1 and A2 show that the TDS concentrations for all water samples collected along the Rosetta branch are greater during summer and winter than during spring and autumn. The increasing rate of water evaporation in summer leads to increased TDS concentrations in the water; During the "winter closing" period, low water level results in the elevation of TDS concentrations. The TDS concentrations along the Rosetta branch fall within the permissible limits specified by Egyptian Law 48/1982 and EPA standards $(\leq 500 \mathrm{mg} / \mathrm{L})[12,13]$, except at Stations $\mathrm{S}_{2}, \mathrm{~S}_{14}$ and $\mathrm{S}_{17}$ (at end of the Rosetta branch). The increase in TDS concentration at Stations $S_{2}$ and
$\mathrm{S}_{14}$ is attributed to the discharge of domestic, agricultural and industrial effluents from El-Rahawy and Sabal drains. On the other hand, the high value of TDS at Station $\mathrm{S}_{17}$ is attributed to intrusion of seawater, which is characterized by high TDS concentration. Rise in water temperatures was also found at Stations $\mathrm{S}_{2}$ and $\mathrm{S}_{14}$ as a result of high TDS concentration. Many organisms can not survive in high temperatures [20].

\subsubsection{Fecal Coliform}

FC, a harmful microbial contaminant, exists in surface waters and may cause diseases such as hepatitis A, gastroenteritis, dysentery, cholera and typhoid fever [21]. The drinking water standard requires that the $\mathrm{FC}$ bacteria be totally absent from potable water [22]. FC bacteria can be found in surface water as a result of discharge of domestic sewage and animal wastes. Along the Rosetta branch, FC values ranged from 450 to $2.496 \times 10^{6} \mathrm{CFU}$ (colony forming units)/100 mL during all seasons. The highest FC values were recorded at Station $\mathrm{S}_{2}$ during all seasons due to the discharge of domestic effluent from the El-Rahawy drain (Tables A1 and A2). The FC values for all water samples collected along the Rosetta branch exceeded the permissible limits specified by Egyptian Law 48/1982 and EPA standards $(\leq 1,000 \mathrm{CFU} / 100 \mathrm{~mL})[12,13]$, except at Stations $\mathrm{S}_{7}$ (upstream of the El-Tahrir drain), $\mathrm{S}_{10}$ (upstream of the Zawyet El-Baher drain), $\mathrm{S}_{13}$ (upstream of the Tala drain) and $\mathrm{S}_{17}$, due to the low discharge of domestic wastewater at these points.

\subsubsection{Dissolved Oxygen}

DO measures the amount of oxygen dissolved in a body of water, and adequate DO concentration proves necessary for aquatic life and good water quality. Oxygen is absorbed in water through photosynthesis, surface water agitation and diffusion from the surrounding air [23]. In the Rosetta branch, the concentration of DO ranged from 2.5 to $7.21 \mathrm{mg} / \mathrm{L}$. More than $91 \%$ of the studied stations along the Rosetta branch did not comply with permissible DO 
limits specified by Egyptian Law 48/1982 and EPA standards ( $\geq 5 \mathrm{mg} / \mathrm{L}$ ) $[12,13]$; These excessive levels resulted from discharge of untreated domestic, agricultural and industrial wastewater to the branch. The lowest DO concentrations were recorded at Station $\mathrm{S}_{2}$, particularly in summer season, where warm water holds more DO than cold water, as shown in Tables A1 and A2. The decline in DO concentration at this point also occurs because of high organic and inorganic matters, as well as because of the nutrient load discharged directly from El-Rahawy drain. The main problem is that most of the aquatic life can not survive at concentrations below $3 \mathrm{mg} / \mathrm{L}$ of DO [24]. In contrast, the highest DO concentrations were recorded at the end of the Rosetta branch as a result of strong mixing between the Rosetta branch and the Mediterranean Sea and as a result of the impact of the prevailing winds from the Mediterranean Sea. Tables $\mathrm{A} 1$ and $\mathrm{A} 2$ also show the DO concentrations increase during spring than during the other seasons; In spring, more sunlight penetrates the water and phytoplankton reproduce rapidly.

3.1.6 Biological Oxygen Demand and Chemical Oxygen Demand

BOD quantifies the amount of oxygen consumed by microorganisms over a 5-day period at a constant temperature of $20^{\circ} \mathrm{C}$, and COD represents the amount of oxygen consumed during the chemical decomposition of organic materials under the effect of strong oxidizing chemicals. Consumption of large amounts of oxygen indicates the presence of large amounts of pollutants in water $[25,26]$. The water quality standard specified in Egyptian Law 48/1982 and EPA standards for BOD and COD is 6 and $10 \mathrm{mg} / \mathrm{L}$, respectively $[12,13]$. The BOD and COD values along the Rosetta branch ranged from 2.4 to $41 \mathrm{mg} / \mathrm{L}$ and from 8 to $63 \mathrm{mg} / \mathrm{L}$, respectively, which clearly exceeded the permissible limits. Tables A1 and A2 show that the highest BOD and COD values were recorded at Stations $S_{2}, S_{5}$ and $S_{14}$, because of the huge amount of domestic, agricultural, and industrial wastewater discharged directly from El-Rahawy, Sabal and Tala drains, all of which contain high loads of organic matter which is undesirable for aquatic life. High COD and BOD concentrations in surface water can cause poor aeration conditions [27]. Tables A1 and $\mathrm{A} 2$ also show that BOD and COD concentrations are greater during winter and summer than during autumn and spring for all water samples collected along the Rosetta branch; The BOD and COD concentrations increase in the winter as a result of the low water level during the winter period and increase in the summer because of the increased rate of water evaporation and the reduced amount of oxygen dissolved in water.

\subsubsection{Temperature}

Temperature governs many important parameters in rivers, including biological activity and growth: the solubility of oxygen in water; and the kinds of organisms, aquatic life and plants that can live in rivers [28]. The change in water temperature occurs as a result of weather conditions, discharges into the river from pollution sources and groundwater inflows. Along the Rosetta branch, the water temperature values ranged from 16.4 to $28.4{ }^{\circ} \mathrm{C}$ during all seasons, as shown in Tables A1 and A2. The maximum water temperatures, recorded in summer, occurred because of the warm air temperatures and the direct exposure to the sunlight. The highest temperature was recorded at Station $\mathrm{S}_{2}$, which occurred because of the elevated TSS concentration discharges from the El-Rahawy drain - the suspended solids absorb heat energy, resulting in a rise in water temperature. The main problem is that organisms can not survive in high water temperatures [20].

\subsubsection{Total Suspended Solids}

TSS can be defined as all particles suspended in water that do not pass through a filter paper $(2 \mu \mathrm{m})$ when a sample of water is filtered. Suspended solids usually include decaying plant matter, silt, clays, industrial wastes, animal matter and domestic wastes [26]. Tables A1 and A2 show that, for all water 
samples collected along the Rosetta branch during all seasons, TSS concentrations exceeded the permissible limits specified by Egyptian Law 48/1982 and EPA standards $(\leq 20 \mathrm{mg} / \mathrm{L})[12,13]$. Because Stations $\mathrm{S}_{2}$, $\mathrm{S}_{5}$ and $\mathrm{S}_{14}$ receive effluents from the El-Rahawy, Sabal and Tala drains, these sites yielded the highest TSS values. The presence of high levels of TSS in river can adversely affect the aquatic life and water quality because suspended particles absorb heat from sunlight, causing an increase in water temperature and a decrease in oxygen production [20].

\subsubsection{Total Organic Carbon}

TOC, a measurement of the amount of organic compounds in water, is often used for evaluation of water quality [29]. Organic compounds in water are either synthetic or naturally occurring. The synthetic organic compounds include solvents, detergents, oils, herbicides, fertilizers and pesticides, whereas the natural organic compounds include tannin, humic and fulvic acids [30]. TOC values along the Rosetta branch ranged from 0.29 to $4 \mathrm{mg} / \mathrm{L}$ during all seasons, as shown in Tables A1 and A2. The highest values were recorded at Stations $S_{2}$ and $S_{14}$, where these drains receive a huge amount of agricultural, domestic and industrial wastewater that contains a high load of organic matter. High TOC concentration in surface water can result in depletion of DO which adversely affects the aquatic life [20].

\subsubsection{Chlorides}

$\mathrm{Cl}^{-}$, or inorganic anions in freshwater and saltwater, are derived from the dissociation of salts such as calcium chloride or sodium chloride [31]. Potential sources of chloride include groundwater, road salts, wastewater effluent, fertilizers and industrial discharge. Tables A1 and A2 show that the chloride values along the Rosetta branch ranged from 60 to $7,150 \mathrm{mg} / \mathrm{L}$ during all seasons. The highest values were recorded at Stations $S_{2}$ (at discharge point of the El-Rahawy drain), $\mathrm{S}_{14}$ (at discharge point of the Tala drain) and $\mathrm{S}_{17}$ (at end of the Rosetta branch). The increase in $\mathrm{Cl}^{-}$concentration at Stations $\mathrm{S}_{2}$ and $\mathrm{S}_{14}$ is attributed to the discharge of pollutants from El-Rahawy and Tala drains at these stations. On the other side, the high value of $\mathrm{Cl}^{-}$at Station $\mathrm{S}_{17}$ is attributed to intrusion of seawater, characterized by high $\mathrm{Cl}^{-}$concentration. High $\mathrm{Cl}^{-}$concentration in the river can make the water unsuitable for drinking and can kill aquatic animals and plants [32].

\subsubsection{Phosphates}

In surface waters, phosphorus usually occurs in the form of $\mathrm{PO}_{4}{ }^{3-}$. Potential sources of phosphate contamination include fertilizers, soil erosion, domestic sewage, industrial wastes and animal wastes [33]. Tables $\mathrm{A} 1$ and $\mathrm{A} 2$ show that $\mathrm{PO}_{4}{ }^{3-}$ values along the Rosetta branch ranged from $<0.1$ to $6.1 \mathrm{mg} / \mathrm{L}$ during all seasons. The highest values were recorded at the discharge point of the El-Rahawy drain (Station $\mathrm{S}_{2}$ ) (Tables A1 and A2), due to receiving flow from agricultural drainage water. The presence of a high concentration of phosphorus and nitrogen in surface water produces large quantities of algae and aquatic plants. In consequence, the level of DO decreases as the algae decay. The $\mathrm{PO}_{4}{ }^{3-}$ is normally absorbed by the algae found in water or removed through the direct adsorption onto the river bed sediments. The results showed $\mathrm{PO}_{4}{ }^{3-}$ concentrations greater during winter; In cold water, the removal of $\mathrm{PO}_{4}{ }^{3-}$ decreases because the algae grow slower in the winter. The main concern is that most of the aquatic life can not survive under low oxygen conditions [24].

\subsubsection{Nitrate}

$\mathrm{NO}_{3}{ }^{-}$, an inorganic compound, consists of one hydrogen ion attached to three oxygen ions. $\mathrm{NO}_{3}{ }^{-}$ does not harm human health unless converted to nitrite $\left(\mathrm{NO}_{2}{ }^{-}\right)$[34]. Potential sources of $\mathrm{NO}_{3}{ }^{-}$ contamination include septic tanks, fertilizers, plant debris, domestic sewage and animal wastes [35]. $\mathrm{NO}_{3}{ }^{-}$ values along the Rosetta branch ranged from 2.95 to $115 \mathrm{mg} / \mathrm{L}$ during all seasons, as shown in Tables A1 and A2. The highest values were recorded at the discharge points of the El-Rahawy and Tala drains, which receive large amounts of untreated and partially 
treated industrial and domestic wastewaters, in addition to agricultural drainage water. For all water samples collected along the Rosetta branch, results showed $\mathrm{NO}_{3}{ }^{-}$concentrations greater during winter and spring than during summer and autumn; In cold water, the nitrification rate (converting ammonium to nitrate) may drop due to decreased microbial and bacterial activity.

\subsection{Correlation Matrix}

The nature of correlations among the different parameters is provided in Tables A3-A6 in the Appendix. Results revealed negative correlations between $\mathrm{pH}$ values and all studied parameters for all seasons, except DO and temperature. Turbidity, BOD, COD, TDS, TSS, TOC, FC, $\mathrm{Cl}^{-}, \mathrm{PO}_{4}{ }^{3-}$ and $\mathrm{NO}_{3}{ }^{-}$ values showed positive correlations with all selected parameters for all seasons, except DO, $\mathrm{pH}$ and temperature. Analytical results also showed a strong positive correlation $(r \approx 0.9999)$ between TDS and $\mathrm{Cl}^{-}$ during all seasons. Negative correlations were found between DO values and all studied parameters for all seasons, except $\mathrm{pH}$ and temperature; This finding indicates the important role of DO in improving water quality and illustrated the extent of the link between DO depletion and the bacterial water deterioration. Strong positive correlations were found between COD and BOD during all seasons. The analyses results showed that fecal coliform, found in the Rosetta branch as a result of discharge of domestic sewage, constitutes the main cause of the poor water quality along the branch. The increase in fecal coliform concentration leads to an equivalent increase in TDS, TSS, COD, BOD and TOC concentrations and to a decrease in $\mathrm{DO}$ and $\mathrm{pH}$ levels.

\subsection{Water Quality Index}

The WQI, calculated seasonally at different points along the study area, provided a simple indicator of water quality at these points. Figs. 2-5 show the WQI values at different stations along the Rosetta branch

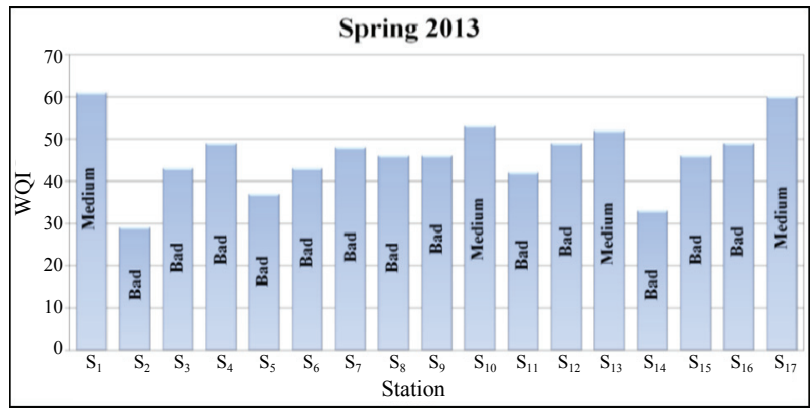

Fig. 2 Water quality index for collected water samples in spring season.

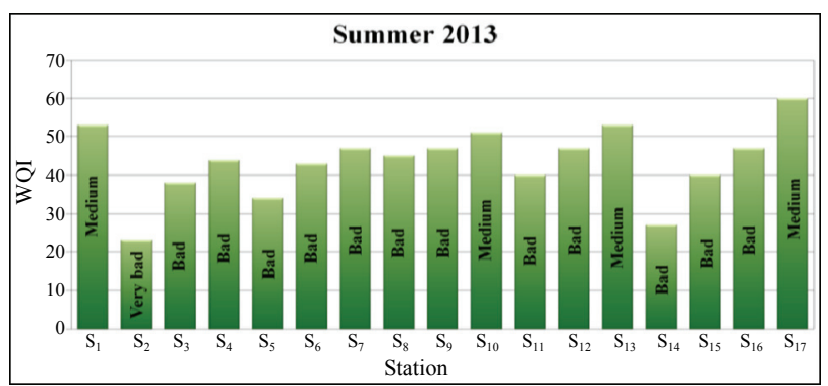

Fig. 3 Water quality index for collected water samples in summer season.

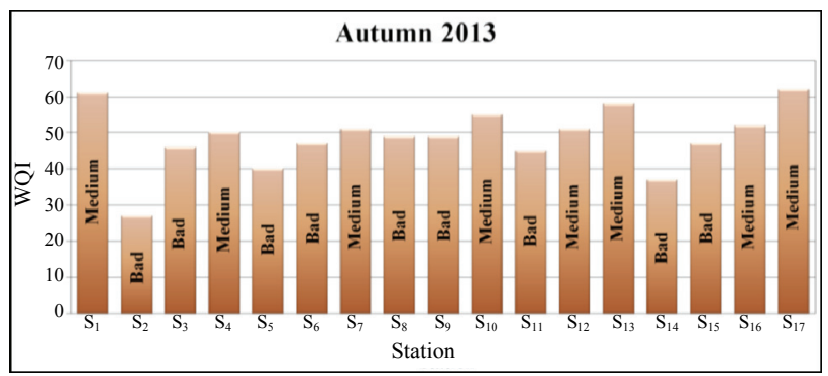

Fig. 4 Water quality index for collected water samples in autumn season.

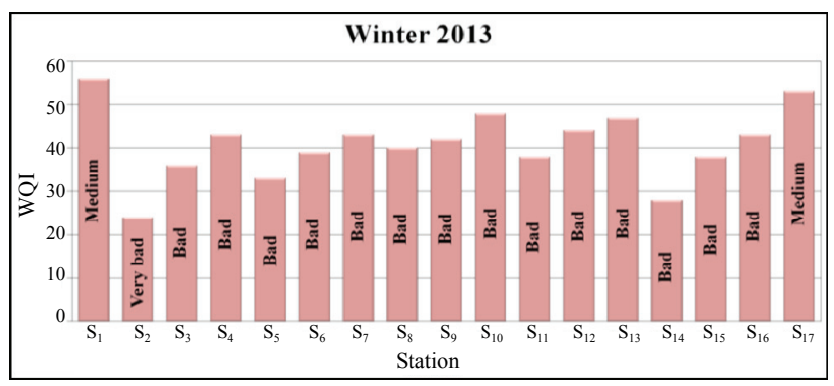

Fig. 5 Water quality index for collected water samples in winter season.

during all the seasons. The worst water quality conditions were recorded during the winter and summer seasons. The concentration of pollutants increases in the winter due to decreased water flow 
during the "winter closing" period; In summer, the elevated rise in water temperature leads to increased rates of water evaporation and, thus, to an increase in the concentration of pollutants. Results of the WQI indicate that the El-Rahawy and the Tala drains comprise the main sources of water pollution along the Rosetta branch because of the large amount of agricultural, domestic and industrial wastewater discharges to those drains. Although water quality upstream of the El-Rahawy drain was classified as medium during all seasons, water quality downstream of the El-Rahawy drain was classified as bad because of discharge received from the drain. Also, upstream of the Tala drain, the water quality was determined to be medium during autumn, summer and spring, and to be bad downstream from the Tala drain. The results of the WQI also showed that FC constitutes the main cause of the poor water quality along the Rosetta branch. The increase in FC concentration leads to an equivalent increase in turbidity levels and to a decrease in DO concentration. Higher turbidity decreases the rate of photosynthesis because the suspended particles absorb more heat and reduce the amount of sunlight penetrating the water; In turn, the decreased photosynthesis leads to a decrease in DO production. An improvement in water quality was observed at
Station $\mathrm{S}_{17}$ (the end of the Rosetta branch), where the FC concentration decreased as a result of the mixing between the Rosetta branch and the Mediterranean Sea.

\subsection{Analysis of Variance}

A two-way ANOVA was used to determine the difference in the water samples collected from five pollution sources and was based on eight parameters: COD, BOD, TSS, TDS, TOC, DO, $\mathrm{pH}$ and $\mathrm{Cl}^{-}$. Table 3 shows the flows from different pollution sources along the Rosetta branch at different seasons, and Table 4 provides results for the mass loading for each parameter at different point sources. The null hypothesis $\left(\mathrm{H}_{0}\right)$ states that there are no differences between the means of the samples, while the alternate hypothesis $\left(\mathrm{H}_{1}\right)$ states that there are differences between the means of the samples. The results of the two-way ANOVA showed a significant difference in the impacts of each pollution source in the mass loading: As Table 4 indicates, the pollution source $p$-value $\left(1.25 \times 10^{-54}\right)$ was found to be significantly less than 0.05 (5.0\% chance that the null hypothesis was true). In this case, the null hypothesis was rejected in favor of an alternative hypothesis. A significant difference was observed between the impacts of each parameter on the mass loading: The

Table 3 Flow from different pollution sources along the Rosetta branch for different seasons.

\begin{tabular}{lllll}
\hline Pollution source & \multicolumn{5}{c}{ Flow $\left(\mathrm{m}^{3} /\right.$ day $)$} \\
\hline Season & Spring 2013 & Autumn 2013 & Winter 2013 & Summer 2013 \\
\hline El-Rahawy drain & $1,900,000$ & $2,000,000$ & $1,950,000$ & $1,850,000$ \\
Sabal drain & 450,757 & 400,000 & 410,000 & 430,000 \\
El-Tahrir drain & 600,045 & 545,000 & 550,000 & 580,000 \\
Zawyet El-Bahr drain & 90,900 & 85,000 & 89,000 & 90,000 \\
Tala drain & 428,000 & 460,000 & 445,000 & 467,000 \\
\hline
\end{tabular}

Table 4 Results of two-way ANOVA with replication at the Rosetta branch.

\begin{tabular}{llllllll}
\hline $\begin{array}{l}\text { Source of } \\
\text { variation }\end{array}$ & $\begin{array}{l}\text { SS (sum of } \\
\text { squares) }\end{array}$ & $d f$ & MS (mean square) & $F$-statistics & $p$-value & $F$-critical & Hypothesis \\
\hline Pollution source & $3.64 \mathrm{E}+23$ & 4 & $9.09 \mathrm{E}+22$ & 169.83 & $1.25 \mathrm{E}-54$ & 2.43 & Alternate hypothesis $\left(\mathrm{H}_{1}\right)$ \\
Parameter & $3.11 \mathrm{E}+23$ & 9 & $3.46 \mathrm{E}+22$ & 64.59 & $3.95 \mathrm{E}-47$ & 1.94 & Alternate hypothesis $\left(\mathrm{H}_{1}\right)$ \\
Interaction & $5.10 \mathrm{E}+23$ & 36 & $1.42 \mathrm{E}+22$ & 26.47 & $1.26 \mathrm{E}-48$ & 1.49 & Alternate hypothesis $\left(\mathrm{H}_{1}\right)$ \\
Within & $8.03 \mathrm{E}+22$ & 150 & $5.35 \mathrm{E}+20$ & & & & \\
Total & $1.27 \mathrm{E}+24$ & 199 & & & & & \\
\hline
\end{tabular}


parameter $p$-value $\left(3.95 \times 10^{-47}\right)$ was found to be significantly less than 0.05 , as shown in Table 4 . In this case, the null hypothesis was rejected in favor of an alternative hypothesis. Also a significant difference between pollution sources and their relationship to the parameters were found: The $F$-value (26.47) exceeded the $F$-critical (1.49), and the interaction $p$-value $\left(1.26 \times 10^{-48}\right)$ was significantly lower than 0.05 . In this case, the null hypothesis was also rejected in favor of an alternative hypothesis. The ranking of the point sources in terms of participation in the mass loading for all the studied groups was as follows: the El-Rahawy drain, the Tala drain, the Sabal drain, the El-Tahrir drain and the Zawyet El-Baher drain (Table A7). For point sources, parameters, and the interaction between them, the null hypothesis was rejected in favor of the alternative hypothesis, and then there is evidence that the differences in the means are statistically significant (Table 4), which means that each point source has a different effect in the Rosetta branch water quality. The results revealed that the El-Rahawy and Tala drains are the major sources of water pollution along the Rosetta branch, where these drains receive wastewater from agricultural, domestic and industrial sources located along its path.

\section{Conclusions}

The results of the physicochemical analysis showed that the worst water quality conditions were recorded during winter and summer seasons because the water flow decreases during the "winter closing" period, leading to an increase in pollution levels, and because the water temperature rises during summer, it leads to an increased rate of water evaporation and, thus, to an increase in pollution levels. The lowest DO concentrations were recorded during the hot summer season, at which time the warmer water has less capacity to hold DO than cold water. In contrast, DO concentrations were lowest during spring than in the other seasons; in the spring, more sunlight penetrates the water, and phytoplankton reproduces rapidly. The highest pollution levels were recorded at the discharge points of the El-Rahawy, Sabal and Tala drains, which receive large amounts of agricultural, domestic and industrial wastes.

The calculated WQI showed medium water quality upstream of the El-Rahawy and Tala drains and bad water quality downstream of those drains because of high levels of pollutants discharged from the two drains. The results of WQI also showed that FC is the main cause of poor water quality along the Rosetta branch, which receives large amounts of untreated and partially treated domestic wastewater from the El-Rahawy, the Sabal and the Tala drains. Better water quality was observed at the end of the Rosetta branch, where the mixing that occurs between the Rosetta branch and the Mediterranean Sea results in increased DO levels and decreased FC concentrations.

The results of ANOVA testing showed a significant difference between the impacts of each point source on the mass loading. The impact of each parameter in the mass loading was found to be significantly different. The results of ANOVA testing also showed a significant difference in the relationship of each parameter to the point sources. The ranking of the drains in terms of their impact on the mass loading at the Rosetta branch is as follows: the El-Rahawy, the Tala, the Sabal, the El-Tahrir and the Zawyet El-Baher.

It was concluded that El-Rahawy, Tala and Sabal drains contribute most to water quality degradation along the Rosetta branch due to a large amount of domestic, agricultural and industrial wastewater discharges to those drains. Because the El-Tahrir drain does not receive domestic or industrial wastes, its effect on the water quality is not significant. The Zawyet El-Baher drain also has a minor effect on the water quality due to its low flow rates from this drain. 


\section{Acknowledgments}

This research was supported by the GAFP (Graduate Assistant Fellowship Program) and the Department of Civil, Construction and Environmental Engineering at the University of Alabama at Birmingham. The authors also thank the Egyptian Housing Building Research Center for their help in collecting samples and performing the chemical analyses.

\section{References}

[1] Nile Basin Initiative. 2005. Nile Basin National Water Quality Monitoring Baseline Study Report for Egypt. Nile Trans Boundary Environmental Action Project.

[2] Abdin, A. E., and Gaafar, I. 2009. "Rational Water Use in Egypt." In Technological Perspectives for Rational Use of Water Resources in the Mediterranean Region, edited by El Moujabber, M., Mandi, L., Trisorio-Liuzzi, G., Martín, I., Rabi, A., and Rodríguez, R. Bari: CIHEAM (Centre International de Hautes Etudes Agronomiques Méditerranéennes).

[3] Ezzat, S. M., Hesham, M. M., Mervat, A. A., Essam, H. A., and Mostafa, A. E. 2012. "Water Quality Assessment of River Nile at Rosetta Branch: Impact of Drains Discharge.” Middle-East J. Scientific Res. 12 (4): 413-23.

[4] Mostafa, M. 2014. "Modeling of Pollutant Transport in the Nile Delta Egypt." Ph.D. dissertation, University of Alabama at Birmingham.

[5] Donia, N. 2005. "Rosetta Branch Waste Load Allocation Model." Presented at the Ninth International Water Technology Conference, Sharm El-Sheikh, Egypt.

[6] El-Bourie, M. M. Y. 2008. "Evaluation of Organic Pollutants in Rosetta Branch Water-River Nile.” M.Sc. thesis, Tanta University.

[7] El-Bouraie, M. M., Eman, A. M., Gehad, G. M., Essam, H. A., and Mohamed, M. Y. 2011. "Water Quality of Rosetta Branch in Nile Delta, Egypt." Suoseura, Helsinki 62 (1): 31-7.

[8] Abdel-Satar, A. M., and Elewa, A. A. 2001. "Water Quality and Environmental Assessments of the River Nile at Rosetta Branch." Presented at 2nd International Conference and Exhibition for Life and Environment, Alexandria, Egypt.

[9] Abdo, M. H. 2002. "Environmental Studies on Rosetta Branch and Some Chemical Applications at the Area Extend from El-Kanater El-Khyria to Kafr-El-Zyat City." Ph.D. thesis, Ain Shams University.

[10] Elewa, A. A., Shehata, M. B., Mohamed, L. F., Badr, M. H., and Abdel-Aziz, G. S. 2009. "Water Quality
Characteristics of the River Nile at Delta Barrage with Special Reference to Rosetta Branch." Global J. Environ. Res. 90 (1): 1-6.

[11] Andrew, D. E., Lenore, S. C., Eugene, W. R., and Arnold, E. G. 2005. Standard Methods for the Examination of Water and Wastewater. 21st ed. Washington, D.C.: American Public Health Association.

[12] U.S. EPA (Environmental Protection Agency). 1988. Water Quality Standards Criteria Summaries. Washington, D.C.: U.S. EPA.

[13] NWRC (National Water Research Center). 1995. River Nile Protection and Development Project Phase II. Report No. A301 0901, Environmental Pollution and Legislative Regulations (Law 48. 1982 \& Decree 8, 1993), Ministry of Public Works and Water Resources.

[14] Tyagi, S., Bhavtosh, S., Prashant, S., and Rajendra, D. 2013. "Water Quality Assessment in Terms of Water Quality Index." Am. J. Water Resources 1 (3): 34-8.

[15] Chin, D. A. 2000. Water-Resources Engineering. Upper Saddle River, New Jersey: Prentice-Hall Inc.

[16] U.S. Environmental Protection Agency. 2012. Water: Monitoring and Assessment. Washington, D.C.: U.S. Environmental Protection Agency.

[17] U.S. Environmental Protection Agency. 2000. Delivering Timely Water Quality Information to Your Community: The Lake Access-Minneapolis Project. Washington, D.C.: U.S. Environmental Protection Agency.

[18] Kochany, J., and Wayne, S. 2001. "Application of Humic Substances in Environmental Remediation. Conestoga-Rovers and Associates." Presented at the WM (Waste Management)' 01 Conference, Tucson, AZ, USA.

[19] World Health Organization. 2003. Total Dissolved Solids in Drinking-Water. 2nd ed. Vol. 2. Geneva: World Health Organization.

[20] Soares, C. 1999. Environmental Technology and Economics: Sustainable Development in Industry. Woburn, MA: Butterworth-Heinemann.

[21] Jolley, L. W., and William, R. E. 2014. Extension Forestry and Natural Resources. Clemson, SC: Clemson Cooperative Extension.

[22] U.S. Environmental Protection Agency. 2013. Drinking Water Contaminants. National Primary Drinking Water Regulations. Washington, D.C.: U.S. Environmental Protection Agency.

[23] Addy, K., and Linda, G. 1997. "Dissolved Oxygen and Temperature." In Natural Resources Facts. Fact sheet No. 96-3. Rhode Island: University of Rhode Island.

[24] Doja, M. N. 2007. International Encyclopaedia of Engineering and Technology. New Delhi: International Scientific Publishing Academy. 
[25] Reynolds, T. D., and Paul, A. R. 1996. Unit Operations and Processes in Environmental Engineering. Stamford, CT: Cengage Learning.

[26] Lin, S. D., and Lee, C. C. 2001. Water and Wastewater Calculations Manual. New York, NY: McGraw-Hill.

[27] Gowariker, V., Krishnamurthy, V. N., Sudha, G., Manik, D., and Kalyani, P. 2009. The Fertilizer Encyclopedia. Hoboken, New Jersey: John Wiley \& Sons, Inc.

[28] Tanner, D. Q., Heather, M. B., and Matthew, M. J. 2012. Total Dissolved Gas and Water Temperature in the Lower Columbia River, Oregon and Washington. Water Year 2012: Quality-Assurance Data and Comparison to Water-Quality Standards. U.S. Geological Survey water-resources investigations report in cooperation with the United States Army Corps of Engineers.

[29] Florescu, D., Andreea, M. I., Diana, C., Elena, H., Roxana, E. I., and Monica, C. 2013. "Validation Procedure for Assessing the Total Organic Carbon in Water Samples.” Rom. J. Phys. 58 (1-2): 211-9.

[30] Whitehead, P. 2003. "Application Note: Laboratory
Monitoring of Total Organic Carbon in Ultrapure Water." American Laboratory 35 (17): 20-24.

[31] World Health Organization. 2003. Chloride in Drinking-Water. 2nd ed. Vol. 2. Geneva: World Health Organization.

[32] OMOE (Ontario Ministry of the Environment). 2003. Water Sampling and Data Analysis Manual for Partners in the Ontario. Ontario: Provincial Water Quality Monitoring Network.

[33] Minnesota Pollution Control Agency. 2007. Phosphorus: Sources, Forms, Impact on Water Quality: A General Overview. Minnesota: Minnesota Pollution Control Agency.

[34] Manahan, S. E. 2013. Fundamentals of Environmental and Toxicological Chemistry: Sustainable Science. Boca Raton, FL: CRC Press.

[35] U.S. Environmental Protection Agency. 2007. Nitrates and Nitrites: TEACH Chemical Summary. Toxicity and Exposure Assessment for Children's Health. Washington, D.C.: U.S. Environmental Protection Agency. 
Appendix

Table A1 The average values of physical and chemical analyses for water samples collected along the Rosetta branch at different seasons (2013).

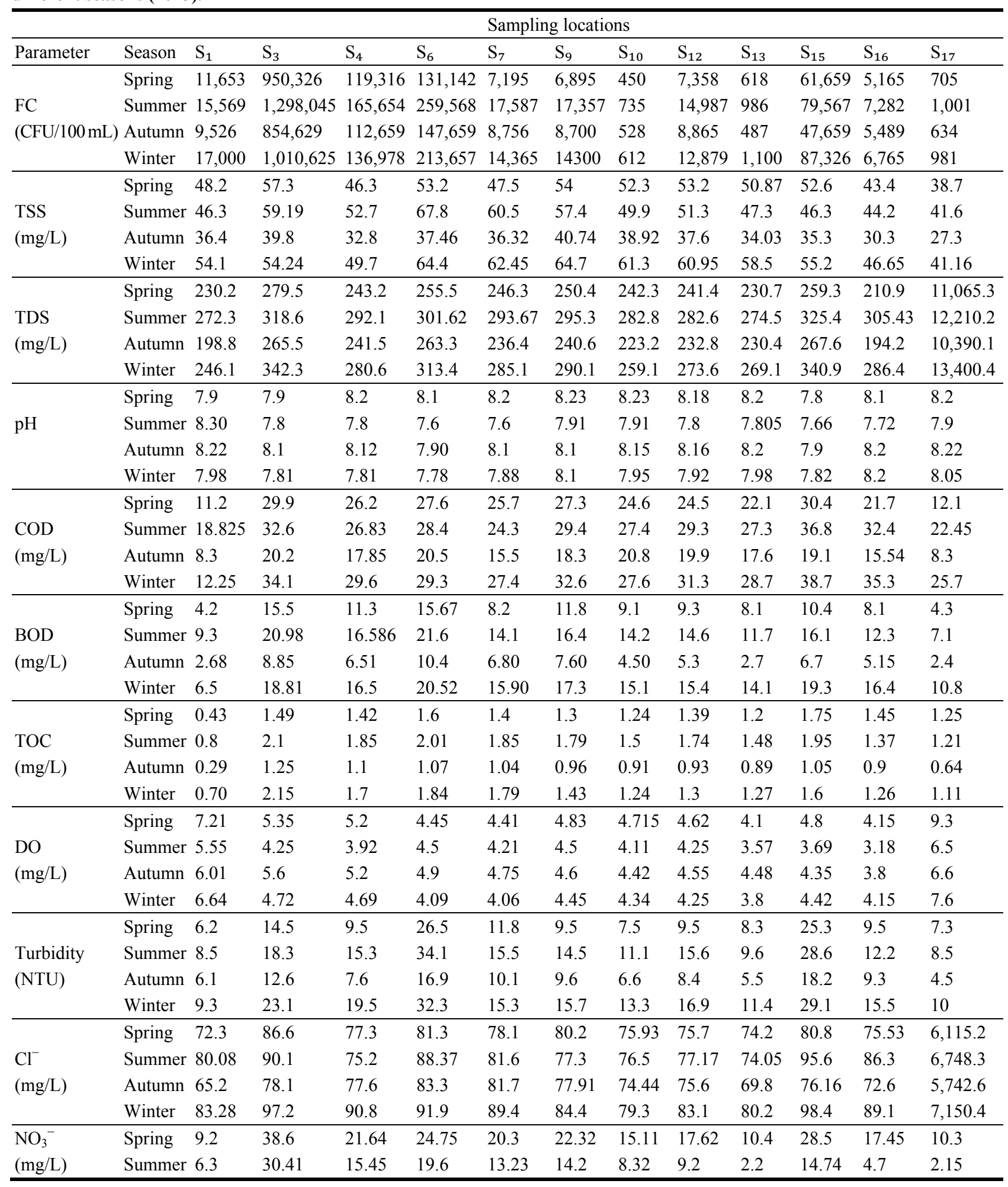


(Table A1 continued)

\begin{tabular}{llllllllllllll}
\hline & \multicolumn{10}{c}{ Sampling locations } \\
\hline Parameter & Season & $\mathrm{S}_{1}$ & $\mathrm{~S}_{3}$ & $\mathrm{~S}_{4}$ & $\mathrm{~S}_{6}$ & $\mathrm{~S}_{7}$ & $\mathrm{~S}_{9}$ & $\mathrm{~S}_{10}$ & $\mathrm{~S}_{12}$ & $\mathrm{~S}_{13}$ & $\mathrm{~S}_{15}$ & $\mathrm{~S}_{16}$ & $\mathrm{~S}_{17}$ \\
\hline $\mathrm{NO}_{3}{ }^{-}$ & Autumn & 3.35 & 35.6 & 19.67 & 22.1 & 16.55 & 17.6 & 10.8 & 11.7 & 4.1 & 17.14 & 6.3 & 3.55 \\
$(\mathrm{mg} / \mathrm{L})$ & Winter & 11.2 & 41.4 & 27.9 & 32.96 & 27.1 & 28.8 & 21.2 & 23.14 & 15.6 & 39.7 & 26.87 & 15.3 \\
\hline \multirow{2}{*}{$\mathrm{PO}_{4}{ }^{3-}$} & Spring & $<0.1$ & 0.38 & $<0.1$ & $<0.1$ & $<0.1$ & $<0.1$ & $<0.1$ & $<0.1$ & $<0.1$ & 0.15 & $<0.1$ & $<0.1$ \\
$(\mathrm{mg} / \mathrm{L})$ & Summer & 0.18 & 0.48 & 0.1 & 0.11 & $<0.1$ & $<0.1$ & $<0.1$ & $<0.1$ & $<0.1$ & 0.41 & 0.105 & $<0.1$ \\
& Autumn & $<0.1$ & 0.26 & $<0.1$ & $<0.1$ & $<0.1$ & $<0.1$ & $<0.1$ & $<0.1$ & $<0.1$ & 0.18 & $<0.1$ & $<0.1$ \\
& Winter & 0.15 & 0.64 & 0.11 & 0.12 & $<0.1$ & $<0.1$ & $<0.1$ & 0.1 & $<0.1$ & 0.33 & $<0.1$ & $<0.1$ \\
\hline \multirow{3}{*}{ Temperature } & Spring & 23.79 & 24.15 & 24.48 & 24.76 & 24.6 & 24.3 & 24.48 & 24.8 & 25.6 & 24.4 & 24.45 & 22.8 \\
$($ Celsius $)$ & Summer & 27.21 & 27.63 & 27.6 & 27.8 & 28.3 & 28.4 & 27.7 & 28.3 & 28.3 & 27.9 & 28.4 & 27.2 \\
& Autumn & 18.80 & 19.18 & 19.52 & 19.80 & 19.59 & 19.34 & 19.52 & 19.56 & 19.59 & 19.4 & 19.49 & 18.3 \\
& Winter & 17.0 & 17.36 & 17.69 & 18.5 & 17.21 & 17.51 & 17.69 & 18.6 & 18.2 & 17.6 & 17.66 & 16.4 \\
\hline
\end{tabular}

Table A2 The average values of physical and chemical analyses for water samples collected at discharge points of pollution sources at different seasons (2013).

\begin{tabular}{|c|c|c|c|c|c|c|}
\hline \multirow[b]{2}{*}{ Parameter } & \multirow[b]{2}{*}{ Season } & \multirow[b]{2}{*}{$\mathrm{S}_{2}$} & \multicolumn{3}{|c|}{ Sampling locations } & \multirow[b]{2}{*}{$\mathrm{S}_{14}$} \\
\hline & & & $\mathrm{S}_{5}$ & $\mathrm{~S}_{8}$ & $\mathrm{~S}_{11}$ & \\
\hline \multirow{4}{*}{$\begin{array}{l}\mathrm{FC} \\
(\mathrm{CFU} / 100 \mathrm{~mL})\end{array}$} & Spring & $1,816,359$ & 250,145 & 915 & 17,500 & 547,986 \\
\hline & Summer & $2,496,385$ & 402,698 & 1,469 & 29,568 & 812,568 \\
\hline & Autumn & $1,453,356$ & 232,567 & 865 & 21,548 & 398,720 \\
\hline & Winter & $2,151,173$ & 345,456 & 1,236 & 32,568 & 750,659 \\
\hline \multirow{4}{*}{$\begin{array}{l}\text { TSS } \\
(\mathrm{mg} / \mathrm{L})\end{array}$} & Spring & 80.4 & 88.5 & 42.3 & 46.87 & 79.6 \\
\hline & Summer & 84.6 & 94.3 & 51.2 & 61.2 & 101.3 \\
\hline & Autumn & 72.6 & 83.1 & 33.4 & 44.2 & 74.9 \\
\hline & Winter & 91.2 & 96.4 & 49.2 & 58.6 & 106.2 \\
\hline \multirow{4}{*}{$\begin{array}{l}\text { TDS } \\
(\mathrm{mg} / \mathrm{L})\end{array}$} & Spring & 421.2 & 372.2 & 300.3 & 272.3 & 401.3 \\
\hline & Summer & 506.3 & 392.3 & 346.5 & 300.4 & 501.4 \\
\hline & Autumn & 416.2 & 312.8 & 265.4 & 275.6 & 356.8 \\
\hline & Winter & 521.4 & 410.3 & 372.6 & 287.12 & 514.4 \\
\hline \multirow{4}{*}{$\mathrm{pH}$} & Spring & 7.47 & 7.9 & 8.2 & 8.14 & 7.62 \\
\hline & Summer & 7.67 & 7.4 & 7.9 & 7.75 & 7.5 \\
\hline & Autumn & 7.3 & 7.82 & 8.21 & 8.2 & 7.7 \\
\hline & Winter & 7.22 & 7.676 & 8.1 & 7.85 & 8.05 \\
\hline \multirow{4}{*}{$\begin{array}{l}\mathrm{COD} \\
(\mathrm{mg} / \mathrm{L})\end{array}$} & Spring & 54.4 & 44.3 & 30.3 & 24.5 & 38.3 \\
\hline & Summer & 63.3 & 48.1 & 38.4 & 33.1 & 56.8 \\
\hline & Autumn & 48.2 & 32.5 & 22.2 & 13.3 & 28.1 \\
\hline & Winter & 55.1 & 40.2 & 41.1 & 38.9 & 54.6 \\
\hline \multirow{4}{*}{$\begin{array}{l}\text { BOD } \\
(\mathrm{mg} / \mathrm{L})\end{array}$} & Spring & 31.2 & 22.6 & 12.23 & 10.5 & 17.3 \\
\hline & Summer & 41.3 & 29.2 & 17.5 & 15.6 & 25.8 \\
\hline & Autumn & 28.1 & 16.2 & 8.3 & 5.7 & 12.3 \\
\hline & Winter & 37.6 & 24.6 & 18.1 & 16.4 & 24.4 \\
\hline \multirow{4}{*}{$\begin{array}{l}\text { TOC } \\
(\mathrm{mg} / \mathrm{L})\end{array}$} & Spring & 3.3 & 2.5 & 2.1 & 1.6 & 2.8 \\
\hline & Summer & 4.5 & 2.7 & 2.4 & 2.6 & 3.8 \\
\hline & Autumn & 2.207 & 1.6 & 1.4 & 1.1 & 2.1 \\
\hline & Winter & 3.1 & 3.2 & 2.3 & 1.671 & 3.25 \\
\hline \multirow{4}{*}{$\begin{array}{l}\text { DO } \\
(\mathrm{mg} / \mathrm{L})\end{array}$} & Spring & 4.35 & 3.8 & 3.45 & 3.78 & 3.34 \\
\hline & Summer & 2.5 & 3.3 & 3.76 & 3.2 & 3.1 \\
\hline & Autumn & 3.62 & 4.1 & 4.12 & 3.86 & 4.025 \\
\hline & Winter & 3.3 & 3.56 & 3.1 & 3.56 & 4.1 \\
\hline
\end{tabular}


(Table A2 continued)

\begin{tabular}{|c|c|c|c|c|c|c|}
\hline & & & Sampli & ons & & \\
\hline Parameter & Season & $\mathrm{S}_{2}$ & $\mathrm{~S}_{5}$ & $\mathrm{~S}_{8}$ & $\mathrm{~S}_{11}$ & $\mathrm{~S}_{14}$ \\
\hline \multirow{4}{*}{$\begin{array}{l}\text { Turbidity } \\
\text { (NTU) }\end{array}$} & Spring & 32.3 & 38.2 & 6.8 & 13.5 & 30.3 \\
\hline & Summer & 38.2 & 49.1 & 14.5 & 23.8 & 52.4 \\
\hline & Autumn & 27.3 & 33.9 & 9.3 & 12.3 & 27.3 \\
\hline & Winter & 40.4 & 52.1 & 16.2 & 22.2 & 54.8 \\
\hline \multirow{4}{*}{$\begin{array}{l}\mathrm{Cl}^{-} \\
(\mathrm{mg} / \mathrm{L})\end{array}$} & Spring & 163.8 & 153.3 & 89.6 & 77.6 & 154.2 \\
\hline & Summer & 149.6 & 115.2 & 77.5 & 80.8 & 170.3 \\
\hline & Autumn & 125.3 & 92.6 & 83.7 & 76.5 & 110.8 \\
\hline & Winter & 190.2 & 161.9 & 85.3 & 99.6 & 194.3 \\
\hline \multirow{4}{*}{$\begin{array}{l}\mathrm{NO}_{3}^{-} \\
(\mathrm{mg} / \mathrm{L})\end{array}$} & Spring & 70.12 & 35.1 & 24.6 & 25.3 & 51.1 \\
\hline & Summer & 47.88 & 26.2 & 15.7 & 16.4 & 30.4 \\
\hline & Autumn & 51.65 & 32.7 & 21.1 & 22.8 & 37.6 \\
\hline & Winter & 81.65 & 42.4 & 31.45 & 32.6 & 63.7 \\
\hline \multirow{4}{*}{$\begin{array}{l}\mathrm{PO}_{4}{ }^{3-} \\
(\mathrm{mg} / \mathrm{L})\end{array}$} & Spring & 4.1 & 0.17 & 0.14 & 0.23 & 0.45 \\
\hline & Summer & 4.48 & 0.32 & 0.2 & 0.33 & 2.7 \\
\hline & Autumn & 3.85 & 0.14 & 0.15 & 0.19 & 0.6 \\
\hline & Winter & 6.1 & 0.25 & 0.19 & 0.34 & $<0.1$ \\
\hline \multirow{4}{*}{$\begin{array}{l}\text { Temperature } \\
\text { (Celsius) }\end{array}$} & Spring & 25.30 & 25.30 & 23.8 & 24.91 & 25.20 \\
\hline & Summer & 28.40 & 27.90 & 28.2 & 27.9 & 28.20 \\
\hline & Autumn & 20.20 & 20.30 & 19.11 & 19.5 & 20.10 \\
\hline & Winter & 18.32 & 18.21 & 17.20 & 18.12 & 18.23 \\
\hline
\end{tabular}

Table A3 Correlation coefficient matrix between water quality parameters for spring 2013.

\begin{tabular}{|c|c|c|c|c|c|c|c|c|c|c|c|c|c|}
\hline Parameter & COD & BOD & TOC & TDS & TSS & $\mathrm{DO}$ & $\mathrm{pH}$ & Temp. & $\mathrm{Cl}^{-}$ & Turbidity & $\mathrm{FC}$ & $\mathrm{NO}_{3}^{-}$ & $\mathrm{PO}_{4}{ }^{3-}$ \\
\hline COD & 1 & & & & & & & & & & & & \\
\hline BOD & 0.96 & 1 & & & & & & & & & & & \\
\hline TOC & 0.93 & 0.89 & 1 & & & & & & & & & & \\
\hline TDS & 0.37 & 0.29 & 0.13 & 1 & & & & & & & & & \\
\hline TSS & 0.84 & 0.83 & 0.76 & 0.28 & 1 & & & & & & & & \\
\hline DO & -0.60 & -0.46 & -0.53 & -0.77 & -0.40 & 1 & & & & & & & \\
\hline $\mathrm{pH}$ & -0.67 & -0.74 & -0.64 & -0.21 & -0.71 & 0.15 & 1 & & & & & & \\
\hline Temp. & -0.58 & -0.54 & -0.45 & -0.71 & -0.59 & 0.78 & 0.34 & 1 & & & & & \\
\hline $\mathrm{Cl}^{-}$ & 0.37 & 0.29 & 0.14 & 0.99 & 0.28 & -0.77 & -0.21 & -0.71 & 1 & & & & \\
\hline Turbidity & 0.81 & 0.81 & 0.78 & 0.19 & 0.86 & -0.38 & -0.77 & -0.54 & 0.19 & 1 & & & \\
\hline $\mathrm{FC}$ & 0.74 & 0.83 & 0.69 & 0.11 & 0.63 & -0.12 & -0.80 & -0.26 & 0.11 & 0.55 & 1 & & \\
\hline $\mathrm{NO}_{3}^{-}$ & 0.90 & 0.92 & 0.90 & 0.24 & 0.78 & -0.41 & -0.83 & -0.44 & 0.24 & 0.76 & 0.89 & 1 & \\
\hline $\mathrm{PO}_{4}{ }^{3-}$ & 0.71 & 0.78 & 0.68 & 0.07 & 0.52 & -0.13 & -0.63 & -0.25 & 0.08 & 0.47 & 0.90 & 0.80 & 1 \\
\hline
\end{tabular}

Table A4 Correlation coefficient matrix between water quality parameters for autumn 2013.

\begin{tabular}{|c|c|c|c|c|c|c|c|c|c|c|c|c|c|}
\hline$\underline{\text { Parameter }}$ & COD & BOD & TOC & TDS & TSS & DO & $\mathrm{pH}$ & Temp. & $\mathrm{Cl}^{-}$ & Turbidity & $\mathrm{FC}$ & $\mathrm{NO}_{3}^{-}$ & $\mathrm{PO}_{4}{ }^{3-}$ \\
\hline$\overline{C O D}$ & 1 & & & & & & & & & & & & \\
\hline BOD & 0.95 & 1 & & & & & & & & & & & \\
\hline TOC & 0.89 & 0.85 & 1 & & & & & & & & & & \\
\hline TDS & 0.31 & 0.22 & 0.25 & 1 & & & & & & & & & \\
\hline TSS & 0.77 & 0.76 & 0.86 & 0.21 & 1 & & & & & & & & \\
\hline DO & -0.61 & -0.49 & -0.62 & -0.62 & -0.53 & 1 & & & & & & & \\
\hline $\mathrm{pH}$ & -0.87 & -0.91 & -0.81 & -0.20 & -0.72 & 0.49 & 1 & & & & & & \\
\hline Temp. & -0.55 & -0.44 & -0.59 & -0.68 & -0.57 & 0.75 & 0.51 & 1 & & & & & \\
\hline
\end{tabular}


(Table A4 continued)

\begin{tabular}{llllllllllllll}
\hline Parameter & COD & BOD & TOC & TDS & TSS & DO & $\mathrm{pH}$ & Temp. & $\mathrm{Cl}^{-}$ & Turbidity & $\mathrm{FC}$ & $\mathrm{NO}_{3}{ }^{-}$ & $\mathrm{PO}_{4}{ }^{3-}$ \\
\hline $\mathrm{Cl}$ & 0.32 & 0.23 & 0.26 & 0.99 & 0.22 & -0.63 & -0.21 & -0.69 & 1 & & & & \\
Turbidity & 0.78 & 0.81 & 0.81 & 0.23 & 0.89 & -0.51 & -0.83 & -0.61 & 0.24 & 1 & & \\
$\mathrm{FC}$ & 0.79 & 0.84 & 0.70 & 0.11 & 0.54 & -0.19 & -0.76 & -0.17 & 0.12 & 0.56 & 1 & \\
$\mathrm{NO}_{3}{ }^{-}$ & 0.85 & 0.89 & 0.91 & 0.29 & 0.79 & -0.44 & -0.78 & -0.48 & 0.30 & 0.80 & 0.83 & 1 & \\
$\mathrm{PO}_{4}{ }^{3-}$ & 0.81 & 0.86 & 0.67 & 0.07 & 0.54 & -0.36 & -0.82 & -0.14 & 0.08 & 0.51 & 0.87 & 0.70 & 1 \\
\hline
\end{tabular}

Table A5 Correlation coefficient matrix between water quality parameters for winter 2013.

\begin{tabular}{|c|c|c|c|c|c|c|c|c|c|c|c|c|c|}
\hline Parameter & COD & BOD & TOC & TDS & TSS & DO & $\mathrm{pH}$ & Temp. & $\mathrm{Cl}^{-}$ & Turbidity & $\mathrm{FC}$ & $\mathrm{NO}_{3}{ }^{-}$ & $\mathrm{PO}_{4}{ }^{3-}$ \\
\hline COD & 1 & & & & & & & & & & & & \\
\hline BOD & 0.87 & 1 & & & & & & & & & & & \\
\hline TOC & 0.85 & 0.87 & 1 & & & & & & & & & & \\
\hline TDS & 0.19 & 0.27 & 0.22 & 1 & & & & & & & & & \\
\hline TSS & 0.60 & 0.62 & 0.68 & 0.50 & 1 & & & & & & & & \\
\hline DO & -0.65 & -0.64 & -0.56 & -0.65 & -0.75 & 1 & & & & & & & \\
\hline $\mathrm{pH}$ & -0.72 & -0.85 & -0.83 & -0.20 & -0.46 & 0.34 & 1 & & & & & & \\
\hline Temp. & -0.51 & -0.56 & -0.50 & -0.61 & -0.52 & 0.68 & 0.57 & 1 & & & & & \\
\hline $\mathrm{Cl}^{-}$ & 0.19 & 0.27 & 0.22 & 0.99 & 0.50 & -0.65 & -0.20 & -0.61 & 1 & & & & \\
\hline Turbidity & 0.75 & 0.77 & 0.91 & 0.22 & 0.59 & -0.43 & -0.83 & -0.60 & 0.22 & 1 & & & \\
\hline $\mathrm{FC}$ & 0.65 & 0.83 & 0.71 & 0.11 & 0.36 & -0.26 & -0.84 & -0.31 & 0.11 & 0.57 & 1 & & \\
\hline $\mathrm{NO}_{3}^{-}$ & 0.90 & 0.95 & 0.90 & 0.24 & 0.58 & -0.50 & -0.90 & -0.48 & 0.24 & 0.81 & 0.87 & 1 & \\
\hline $\mathrm{PO}_{4}{ }^{3-}$ & 0.64 & 0.82 & 0.59 & 0.07 & 0.39 & -0.29 & -0.79 & -0.29 & 0.08 & 0.45 & 0.93 & 0.82 & 1 \\
\hline
\end{tabular}

Table A6 Correlation coefficient matrix between water quality parameters for summer 2013.

\begin{tabular}{|c|c|c|c|c|c|c|c|c|c|c|c|c|c|}
\hline Parameter & COD & BOD & TOC & TDS & TSS & $\mathrm{DO}$ & $\mathrm{pH}$ & Temp. & $\mathrm{Cl}^{-}$ & Turbidity & $\mathrm{FC}$ & $\mathrm{NO}_{3}^{-}$ & $\mathrm{PO}_{4}{ }^{3-}$ \\
\hline COD & 1 & & & & & & & & & & & & \\
\hline BOD & 0.89 & 1 & & & & & & & & & & & \\
\hline TOC & 0.95 & 0.91 & 1 & & & & & & & & & & \\
\hline TDS & 0.22 & 0.32 & 0.23 & 1 & & & & & & & & & \\
\hline TSS & 0.80 & 0.82 & 0.86 & 0.25 & 1 & & & & & & & & \\
\hline DO & -0.76 & -0.67 & -0.70 & -0.58 & -0.54 & 1 & & & & & & & \\
\hline $\mathrm{pH}$ & -0.60 & -0.58 & -0.63 & -0.16 & -0.69 & 0.60 & 1 & & & & & & \\
\hline Temp. & -0.52 & -0.31 & -0.55 & -0.46 & -0.46 & 0.71 & 0.53 & 1 & & & & & \\
\hline $\mathrm{Cl}^{-}$ & 0.23 & 0.33 & 0.24 & 0.99 & 0.26 & -0.60 & -0.16 & -0.46 & 1 & & & & \\
\hline Turbidity & 0.82 & 0.80 & 0.83 & 0.22 & 0.93 & -0.62 & -0.77 & -0.43 & 0.23 & 1 & & & \\
\hline FC & 0.74 & 0.85 & 0.76 & 0.11 & 0.58 & -0.51 & -0.28 & -0.07 & 0.12 & 0.51 & 1 & & \\
\hline $\mathrm{NO}_{3}^{-}$ & 0.83 & 0.95 & 0.90 & 0.29 & 0.79 & -0.60 & -0.49 & -0.23 & 0.29 & 0.75 & 0.90 & 1 & \\
\hline $\mathrm{PO}_{4}{ }^{3-}$ & 0.85 & 0.82 & 0.85 & 0.09 & 0.65 & -0.50 & -0.31 & -0.30 & 0.10 & 0.61 & 0.88 & 0.81 & 1 \\
\hline
\end{tabular}

Table A7 Interaction between organic and solid factors from different pollution sources along the Rosetta branch.

\begin{tabular}{|c|c|c|c|c|c|c|c|c|c|c|}
\hline $\begin{array}{l}\text { PS/ } \\
\text { parameter }\end{array}$ & $\begin{array}{l}\text { COD, } \\
\mathrm{TSS} \\
\mathrm{mg}^{2} / \mathrm{L} \cdot \text { day }\end{array}$ & $\begin{array}{l}\text { COD, } \\
\mathrm{TDS} \\
\mathrm{mg}^{2} / \mathrm{L} \cdot \text { day }\end{array}$ & $\begin{array}{l}\text { BOD, } \\
\mathrm{TSS} \\
\mathrm{mg}^{2} / \mathrm{L} \cdot \text { day }\end{array}$ & $\begin{array}{l}\text { BOD, } \\
\text { TDS } \\
\mathrm{mg}^{2} / \mathrm{L} \cdot \text { day }\end{array}$ & $\begin{array}{l}\text { TOC, } \\
\text { TSS } \\
\mathrm{mg}^{2} / \mathrm{L} \cdot \text { day } \\
\end{array}$ & $\begin{array}{l}\text { TOC, } \\
\text { TDS } \\
\mathrm{mg}^{2} / \mathrm{L} \cdot \text { day } \\
\end{array}$ & $\begin{array}{l}\mathrm{Cl}^{-}, \\
\mathrm{TSS}^{2} \\
\mathrm{mg}^{2} / \mathrm{L} \cdot \text { day }\end{array}$ & $\begin{array}{l}\mathrm{Cl}^{-}, \\
\mathrm{TDS}^{2} \\
\mathrm{mg}^{2} / \mathrm{L} \cdot \text { day }\end{array}$ & $\begin{array}{l}\mathrm{DO}, \\
\mathrm{mg} / \text { day }\end{array}$ & $\mathrm{pH}$ \\
\hline & $7.7 \mathrm{E}+10$ & $4.2 \mathrm{E}+11$ & $4.0 \mathrm{E}+10$ & $2.2 \mathrm{E}+11$ & $3.4 \mathrm{E}+9$ & $1.9 \mathrm{E}+10$ & $7.7 \mathrm{E}+10$ & $4.2 \mathrm{E}+11$ & 0 & +7 \\
\hline PS1 & $1.4 \mathrm{E}+11$ & $5.2 \mathrm{E}+11$ & $8.0 \mathrm{E}+10$ & $2.9 \mathrm{E}+11$ & $4.2 \mathrm{E}+9$ & $1.5 \mathrm{E}+10$ & $1.1 \mathrm{E}$ & $3.9 \mathrm{E}$ & -6 & +7 \\
\hline PS & $6.4 \mathrm{E}+10$ & $3.1 \mathrm{E}+11$ & $3.7 \mathrm{E}+10$ & $1.8 \mathrm{E}+11$ & $1.8 \mathrm{E}+9$ & $8.4 \mathrm{E}+9$ & $5.8 \mathrm{E}+10$ & $2.8 \mathrm{E}+11$ & 2.1 & $1.5 \mathrm{E}+7$ \\
\hline & $5.9 \mathrm{E}+10$ & $2.7 \mathrm{E}+11$ & $3.1 \mathrm{E}+10$ & $1.4 \mathrm{E}+11$ & $2.2 \mathrm{E}+9$ & $1.0 \mathrm{E}+10$ & $6.7 \mathrm{E}+10$ & $3.1 \mathrm{E}+11$ & +6 & $1.4 \mathrm{E}+7$ \\
\hline PS2 & $1.1 \mathrm{E}+10$ & $3.7 \mathrm{E}+10$ & $5.1 \mathrm{E}+9$ & $1.8 \mathrm{E}+10$ & $8.0 \mathrm{E}+8$ & $2.9 \mathrm{E}+9$ & $2.3 \mathrm{E}+10$ & $8.1 \mathrm{E}+10$ & $1.1 \mathrm{E}+6$ & $3.6 \mathrm{E}+6$ \\
\hline
\end{tabular}


(Table A7 continued)

\begin{tabular}{|c|c|c|c|c|c|c|c|c|c|c|}
\hline $\begin{array}{l}\mathrm{PS} / \\
\text { parameter }\end{array}$ & $\begin{array}{l}\text { COD, } \\
\mathrm{TSS} \\
\mathrm{mg}^{2} / \mathrm{L} \cdot \text { day }\end{array}$ & $\begin{array}{l}\text { COD, } \\
\mathrm{TDS} \\
\mathrm{mg}^{2} / \mathrm{L} \cdot \text { day }\end{array}$ & $\begin{array}{l}\text { BOD, } \\
\mathrm{TSS} \\
\mathrm{mg}^{2} / \mathrm{L} \cdot \text { day }\end{array}$ & $\begin{array}{l}\text { BOD, } \\
\mathrm{TDS} \\
\mathrm{mg}^{2} / \mathrm{L} \cdot \text { day }\end{array}$ & $\begin{array}{l}\text { TOC, } \\
\mathrm{TSS}^{2} \\
\mathrm{mg}^{2} / \mathrm{L} \cdot \text { day }\end{array}$ & $\begin{array}{l}\text { TOC, } \\
\text { TDS } \\
\mathrm{mg}^{2} / \mathrm{L} \cdot \text { day }\end{array}$ & $\begin{array}{l}\mathrm{Cl}^{-}, \\
\mathrm{TSS}^{2} \\
\mathrm{mg}^{2} / \mathrm{L} \cdot \text { day }\end{array}$ & $\begin{array}{l}\mathrm{Cl}^{-}, \\
\mathrm{TDS}^{2} \\
\mathrm{mg}^{2} / \mathrm{L} \cdot \text { day }\end{array}$ & $\begin{array}{l}\mathrm{DO}, \\
\mathrm{mg} / \text { day }\end{array}$ & $\mathrm{pH}$ \\
\hline 2 & $1.5 \mathrm{E}+10$ & $4.9 \mathrm{E}+10$ & $9.1 \mathrm{E}+9$ & $3.0 \mathrm{E}+10$ & $3.6 \mathrm{E}+8$ & $1.2 \mathrm{E}+9$ & $1.2 \mathrm{E}+10$ & $4.0 \mathrm{E}+10$ & $1.0 \mathrm{E}+6$ & $3.1 \mathrm{E}+6$ \\
\hline$S 2$ & $3.4 \mathrm{E}+9$ & $3.0 \mathrm{E}+10$ & $1.6 \mathrm{E}+9$ & $1.5 \mathrm{E}+10$ & $4.8 \mathrm{E}+7$ & $4.3 \mathrm{E}+8$ & $3.0 \mathrm{E}+9$ & $2.7 \mathrm{E}+10$ & $9.0 \mathrm{E}+5$ & $.2 \mathrm{E}+6$ \\
\hline PS2 & $1.1 \mathrm{E}+10$ & $4.4 \mathrm{E}+10$ & $6.9 \mathrm{E}+9$ & $2.7 \mathrm{E}+10$ & $1.7 \mathrm{E}+8$ & $6.6 \mathrm{E}+8$ & $1.2 \mathrm{E}+10$ & $4.6 \mathrm{E}+10$ & $9.0 \mathrm{E}+5$ & $3.6 \mathrm{E}+6$ \\
\hline PS3 & $3.1 \mathrm{E}+9$ & $1.1 \mathrm{E}+10$ & $1.5 \mathrm{E}+9$ & $5.4 \mathrm{E}+9$ & $1.7 \mathrm{E}+8$ & $6.1 \mathrm{E}+8$ & $8.6 \mathrm{E}+9$ & $3.1 \mathrm{E}+10$ & $2.1 \mathrm{E}+6$ & 6 \\
\hline S) & $5.2 \mathrm{E}+9$ & $1.8 \mathrm{E}+10$ & $2.7 \mathrm{E}+9$ & $9.4 \mathrm{E}+9$ & $1.4 \mathrm{E}+8$ & $4.8 \mathrm{E}+8$ & $6.1 \mathrm{E}+9$ & $2.1 \mathrm{E}+10$ & $2.2 \mathrm{E}+6$ & $\begin{array}{c}0 \\
0\end{array}$ \\
\hline & $2.0 \mathrm{E}$ & $7.4 \mathrm{E}$ & $7.3 \mathrm{E}+8$ & $2.8 \mathrm{E}$ & $1.1 \mathrm{E}+8$ & 8 & 6.6 & $2.5 \mathrm{E}+$ & -6 & \\
\hline S3 & $8.8 \mathrm{E}+9$ & $3.0 \mathrm{E}+10$ & $5.2 \mathrm{E}+9$ & $1.8 \mathrm{E}+10$ & $2.5 \mathrm{E}+8$ & $8.5 \mathrm{E}+8$ & $6.7 \mathrm{E}+9$ & $2.3 \mathrm{E}+10$ & $1.4 \mathrm{E}+6$ & $4.4 \mathrm{E}+$ \\
\hline PS4 & $7.5 \mathrm{E}+8$ & $5.6 \mathrm{E}+9$ & $3.6 \mathrm{E}+8$ & $2.7 \mathrm{E}+9$ & $2.0 \mathrm{E}+7$ & $1.5 \mathrm{E}+8$ & $5.9 \mathrm{E}+8$ & $4.4 \mathrm{E}+9$ & $2.3 \mathrm{E}+5$ & $7.2 \mathrm{E}+5$ \\
\hline PS4 & $2.3 \mathrm{E}+8$ & $2.6 \mathrm{E}+9$ & $1.2 \mathrm{E}+8$ & $1.4 \mathrm{E}+9$ & $6.6 \mathrm{E}+6$ & $7.6 \mathrm{E}+7$ & $2.2 \mathrm{E}+8$ & $2.5 \mathrm{E}+9$ & $3.6 \mathrm{E}+5$ & $7.1 \mathrm{E}+5$ \\
\hline PS4 & $5.7 \mathrm{E}+8$ & $3.4 \mathrm{E}+9$ & $2.7 \mathrm{E}+8$ & $1.7 \mathrm{E}+9$ & $9.3 \mathrm{E}+6$ & $5.6 \mathrm{E}+7$ & $5.6 \mathrm{E}+8$ & $3.4 \mathrm{E}+9$ & $3.3 \mathrm{E}+5$ & $7.0 \mathrm{E}+5$ \\
\hline $\mathrm{S} 4$ & $8.4 \mathrm{E}+8$ & $5.4 \mathrm{E}+9$ & $3.9 \mathrm{E}+8$ & $2.5 \mathrm{E}+9$ & $1.3 \mathrm{E}+7$ & $8.1 \mathrm{E}+7$ & $6.5 \mathrm{E}+8$ & $4.2 \mathrm{E}+9$ & $2.6 \mathrm{E}+5$ & $6.8 \mathrm{E}+5$ \\
\hline S5 & $7.0 \mathrm{E}+9$ & $7.0 \mathrm{E}+10$ & $3.4 \mathrm{E}+9$ & $3.5 \mathrm{E}+10$ & $3.9 \mathrm{E}+8$ & $3.9 \mathrm{E}+9$ & $1.02 \mathrm{E}+10$ & $1.02 \mathrm{E}+11$ & $9.0 \mathrm{E}+5$ & $3.3 \mathrm{E}+6$ \\
\hline PS5 & $6.3 \mathrm{E}+9$ & $1.3 \mathrm{E}+11$ & $3.5 \mathrm{E}+9$ & $7.1 \mathrm{E}+10$ & $2.1 \mathrm{E}+8$ & $4.1 \mathrm{E}+9$ & $6.23 \mathrm{E}+9$ & $1.24 \mathrm{E}+11$ & $1.4 \mathrm{E}+6$ & $3.7 \mathrm{E}+6$ \\
\hline PS5 & $4.4 \mathrm{E}+9$ & $8.2 \mathrm{E}+10$ & $2.3 \mathrm{E}+9$ & $4.2 \mathrm{E}+10$ & $9.7 \mathrm{E}+7$ & $1.8 \mathrm{E}+9$ & $3.97 \mathrm{E}+9$ & $7.34 \mathrm{E}+10$ & $1.6 \mathrm{E}+6$ & $3.4 \mathrm{E}+6$ \\
\hline PS5 & $1.4 \mathrm{E}+10$ & $6.9 \mathrm{E}+10$ & $8.0 \mathrm{E}+9$ & $4.1 \mathrm{E}+10$ & $2.7 \mathrm{E}+8$ & $1.38 \mathrm{E}+9$ & $9.41 \mathrm{E}+9$ & $4.76 \mathrm{E}+10$ & $1.1 \mathrm{E}+6$ & $3.5 \mathrm{E}+6$ \\
\hline
\end{tabular}

PS: pollution source, PS1: El-Rahawy drain; PS2: Sabal drain; PS3: El-Tahrir drain; PS4: Zawyet El-Baher drain; PS5: Tala drain. 